\title{
ПСИХОЛОГО-ДИДАКТИЧНЕ ПІДГРУНТЯ НАВЧАННЯ АНГЛОМОВНОГО СПІЛКУВАННЯ МАЙБУТНІХ ФАХІВЦІВ ФЛОТУ
}

\author{
Огородник Н. $\boldsymbol{\epsilon}$., \\ канд. пед. наук, доцент, Херсонська державна морська академія, м. Херсон, Украӥна \\ ORCID ID: https://orcid.org/0000-0003-1831-2275
}

DOI: https://doi.org/10.31435/rsglobal_ijitss/30062020/7131

\section{ARTICLE INFO}

Received 11 April 2020

Accepted 13 June 2020

Published 30 June 2020

\section{KEYWORDS}

future seafarers, English-language communication skills, identity crisis, leading activity, intellectualization of cognitive processes.

\begin{abstract}
Among the basic principles of the English-language communication skills development for future seafarers is the principle of consciousness. Being implemented in a teaching and learning process it provides understanding as a fundamental component of the future seafarers' professional competence. As a result, all the aspects of language knowledge (linguistic, speech, and linguosociocultural issues) are processed by the students consciously. They also become able to communicate in full compliance with a communicative situation and a specific cultural context. Moreover, effective learning tactics and strategies that students master reasonably are expected to facilitate them in their further life-long learning process.

The students' age, which is characterized by psychologists as a young adulthood, has a tendency for intellectual development. According to the scientists, at this particular period of time the change of a development focus takes its place, caused by a crucial point in human evolution. The sophisticated identity crisis of 17-year-olds occurs owing to the mismatch between the individual development and the social situation. Another situation, mediated by the educational and professional activity, as a leading one for this age is recognized as a factor that activates the comprehensive personality transformation and starts a new stage of mental development in adolescence, resulting in the intellectualization of all the cognitive processes, and therefore to a more deliberate mastery of knowledge.
\end{abstract}

Citation: Ohorodnyk N. Ye. (2020) Psychological and Didactic Fundamentals for Future Seafarers' English-language Communication Teaching. International Journal of Innovative Technologies in Social Science. 5(26). doi: 10.31435/rsglobal_ijitss/30062020/7131

Copyright: (C) 2020 Ohorodnyk N. Ye. This is an open-access article distributed under the terms of the Creative Commons Attribution License (CC BY). The use, distribution or reproduction in other forums is permitted, provided the original author(s) or licensor are credited and that the original publication in this journal is cited, in accordance with accepted academic practice. No use, distribution or reproduction is permitted which does not comply with these terms.

В умовах відкритого та взаємопов'язаного світу соціально-освітня значущість англійської мови як інструменту міжнародної взаємодії суттєво зросла. 3 отриманням статусу обов'язкової кваліфікаційної складової професійної компетентності сучасного фахівця професійно орієнтоване навчання англійської мови на сьогодні стало одним із пріоритетних напрямків в оновленні освіти.

Закономірним, на думку науковців, $є$ той факт, що зі зміною соціального попиту на якість освіти відбувається і зміна освітніх парадигм [9, с. 10] Старі моделі, розраховані на інші часи й обставини, не в змозі задовільнити нові потреби сучасного процесу навчання та підготовки фахівців. Зростання значення англомовного спілкування у професійній діяльності моряків спричинюе нагальну потребу в переоцінці місця та ролі англійської мови в навчальному процесі, перегляді підходів і технологій навчання, зміні способів навчальної взаємодії на занятті тощо.

Забезпечити ефективність нової моделі навчального процесу, узгодженість усіх іï складових, як-от цілей, методів, засобів й організаційних форм, мають принципи навчання. Як вихідні положення, що покликані регулювати і стратегію і тактику навчального процесу на 
будь-якому його етапі, саме вони забезпечують скерованість запроваджуваної методичної моделі на потрібний результат [12, с.110; 17, с. 40].

Поділяємо позицію вчених, за якою для кожної парадигми вибудовується свій базис [14, с.83; 17, с.139; 20, с. 88]. За відсутності в методиці єдиної класифікації принципів, автори тих чи інших моделей навчання зазвичай укладають свою методологічну та концептуальну основу, обгрунтовуючи провідну роль обраних ними засад. Формуючи фундамент нової концепції навчання, розробники мають обирати між кількома варіантами класифікацій базових положень, як-от: - дидактичні, лінгвістичні, психологічні та методичні принципи навчання, за А.М. Щукіним [21]; - загальнодидактичні, загальнометодичні, специфічні та спеціальні принципи, згідно 3 Г.В. Роговою [17, с. 40], - загальнодидактичні та суто методичні принципи у Н.Д. Гальскової [14, с. 82], Н.І. Гез [4, с. 61], С.Ю. Ніколаєвої [12, с. 110], О.Б. Тарнапольського [20, с. 84].

Навіть при дуже побіжному погляді очевидним є дидактичне, або загальнодидактичне підгрунтя, на яке зазвичай спирається методика навчання як дисципліна, що входить до складу педагогічних наук. Практично всі дослідники питання відзначають відносну універсальність загальнодидактичних принципів, зауважуючи про їхню певну трансформацію у зв’язку 3 багатьма параметрами, серед яких - специфіка предмету навчання, тип навчального закладу, обраний підхід до навчання тощо $[14,20]$.

Проаналізувавши наукові дослідження щодо актуальних на сучасному етапі принципів навчання іноземних мов $[9,12,17,18,20]$, ми виокремили ті з них, що якнайкраще, на нашу думку, корелюють з сучасною компетентнісною моделлю навчання англомовного спілкування майбутніх фахівців флоту.

Так, серед основоположних загальнодидактичних принципів обираємо принщип свідомості, що реалізується всією організацією навчання і передбачає:

- по-перше, свідоме оперування навчальним матеріалом різного характеру (мовним, мовленнєвим, лінгвосоціокультурним);

- по-друге, розуміння алгоритмів виконання певних мовленнєвих дій та особливостей їх подальшого втілення у зв' язному мовленні з урахуванням певного культурного контексту;

- по-трете, осмислене оволодіння ефективними навчальними стратегіями і тактиками.

Дотримання даного принципу чітко прослідковується й у засадничих документах Міжнародної морської організації (ММО). Так, визначаючи стандарти підготовки та дипломування моряків, Конвенція ПДНВ в основу професійної компетентності серед інших складників включає поняття understanding [22], тобто розуміння як сформовану здатність осмислити й осягнути значення, зміст або сутність засвоюваних знань, умінь, навичок, а також виниклих у зв'язку з цим звичних способів дії, або звичок [1, с.203]. Інакше кажучи, вимагається свідоме набуття необхідного для майбутньої професії теоретичного і практичного досвіду, що безпосередньо й становить сутність процесу навчання у його сучасному трактуванні $[13$, с. 145,148$]$.

Ураховуючи той факт, що навчання взагалі психологічно грунтується на досягненні розуміння, як певного моменту, що опосередковує процес отримання знань, надаючи йому сенсу $[13$, с. 20], вочевидь, що й формування комунікативної компетентності в англомовному професійному спілкуванні також має відбуватися шляхом осмисленого оволодіння всіма компонентами змісту навчання.

Зрозуміло, що завдяки свідомому засвоєнню як предметного, так і процесуального аспектів змісту такого навчання в умовах професійної освіти, передусім, розраховують досягти «усвідомлення в мові позамовного світу» [19, с. 15], в нашому випадку, певних професійних знань, здобутих майбутніми моряками англійською мовою. Безумовно, це $\epsilon$ значним внеском у розвиток професійної свідомості фахівця, серед компонентів якої, саме знання, вміння та навички визнаються найважливішим засобом іiі формування. А спроможність здобувати знання нерідною, як-от англійською мовою, що є робочою для моряків, ще й суттєво прискорює їх професійну самоідентифікацію, як таких, що відповідають міжнародним стандартам професіоналізму.

Проте, не виключено, що також вдасться досягти й «усвідомлення самої мови» [19, с. 15], сприяючи тим самим розвитку мовної свідомості майбутніх фахівців, об'єктом якої є мовні знання, мовна особистість, культура мови, мовленнєва поведінка тощо. Певно, що такі досягнення, хоча й не становлять головної мети професійно орієнтованого навчання англомовного спілкування, втім $\epsilon$ досить цінними супутніми здобутками для формованої професійної компетентності майбутнього моряка взагалі та її ключової складової - англомовної комунікативної компетентності зокрема. 
Виходячи $з$ цих позицій, а також беручи до уваги психологічні особливості студентського віку, що, за періодизацією дослідників, здебільшого визначається, як зріла або пізня юність 3 віковими межами, переважно, від 17 до 21 року [3, 5, 15], відзначимо одну з найважливіших, на переконання вчених, потреб особистості даного віку, а саме потребу в інтелектуальному розвитку [7]. Зрозуміло, що на даний віковий період загальні розумові здібності вже сформовано і певні базові знання вже отримано. Між тим, саме в цей час відбувається зміна акцентів розвитку, спричинена черговим переламним моментом в еволюції людини, яким, за визначенням Л. Виготського, є складна особистісно-смислова криза 17 років, відома ще як «велика криза», або криза ідентичності.

Виняткової значущості, на думку вчених, їй надає особливість переходу [2, с. 152]. Будучи останньою кризою дитинства, вона, за оцінкою фахівців, є найбільш яскравою та визначальною, оскільки відображає кульмінаційний момент особистісного перетворення: перехід на якісно новий етап вікового розвитку - від дитинства до дорослості [2, с. 152].

Означена вікова криза, як і будь-яка інша, вирішує своє протиріччя і зумовлена невідповідністю рівня психологічного розвитку особистості тій соціальній ситуації, в якій вона знаходиться, та потребою в іншій ситуації, опосередкованій такою провідною діяльністю, за якої відбуватиметься ії подальший гармонійний розвиток $[3,6]$. Науково доведено, що зміна соціальної ситуації розвитку та звичного способу життя, як-от вступ до вищого навчального закладу та необхідність професійного й особистісного самовизначення, зумовлюють суттєву перебудову всієї структури свідомості, забезпечуючи тим самим психологічну готовність до вирішення суперечностей студентського віку [6 ].

Оскільки провідною, отже головною за значенням для психічного розвитку діяльністю в юнацькому віці знову стає навчальна, точніше навчально-професійна діяльність, відтак саме навчання визнається тим чинником, що зрушує механізми всебічного перетворення особистості та породжує специфічні для даного віку психологічні новоутворення [6, с. 11-12]. Якісними новоутвореннями юнацького віку, за даними психології, стають рефлексія (в окремих джерелах саморефлексія) та пов’язані з нею процеси занурення в особистий психологічний простір задля усвідомлення власної індивідуальності шляхом самоаналізу, самопізнання, самовизначення, або самоідентифікації [6].

Відповідно до загальноприйнятого в психологічній літературі визначення, навчальнопрофесійною діяльністю вважається форма діяльності, спрямована на засвоєння професійних знань, набуття спеціальних умінь i навичок, розвиток професійно значущих якостей $\mathrm{i}$ формування загальної професійної культури [8, с. 363]. Активно поєднуване з різними видами праці, суспільно-орієнтоване, за визначенням учених, професійне навчання розпочинає нову стадію психічного розвитку в юнацькому віці, характерною особливістю якого $\epsilon$ інтелектуалізація всіх пізнавальних процесів [6, с. 14]. Варто відзначити також, що зі зміною соціальної позиції суттєво зростає для юнаків і значущість самого навчання, в якому вбачається можливість професійного самовизначення, самоактуалізації та самоперетворення.

Серед дослідників особливостей психічного розвитку в юнацькому віці - велика кількість вітчизняних і зарубіжних вчених: П.П. Блонський, Л.С. Виготський, О.Г. Видра, П.Я. Гальперін, А.З. Зак, І.С. Кон, Н.С. Лейтес, О.М. Матюшкін, В.С. Мухіна, Р.В. Павелків, В.М. Поліщук, П. Піаже, E.H.Ericson, J.E. Marsiaта та ін. Стрімкий та бурхливий інтелектуальний розвиток, відзначуваний психологами в юнацькому віці, супроводжується надзвичайно важливими якісними трансформаціями. Оскільки центром когнітивного розвитку стає формування словесно-логічного, або абстрактного мислення $[3,15,16]$, як найвищого прояву розвитку мислення взагалі, відповідно, на якісно новий рівень піднімаються й усі інші вищі психічні процеси.

Так, знаходячись у прямій залежності від організації розумової діяльності, суттєво «дорослішає» механізм пам'яті юнаків. За даними вікової психології, зі зростанням продуктивності мимовільної пам'яті, роль якої не зменшується в юнацькому віці, прискореними темпами вдосконалюються здібності до більш ефективного довільного запам'ятовування завдяки активному та свідомому залученню раціональних прийомів i способів опрацювання інформації. Залежна за способом запам'ятовування від особистої волі та свідомості довільна пам'ять юнаків за своїм змістом і за способом відтворення того, що запам'ятовується, $є$ словесно-логічною пам'яттю, а відтак, обумовленою вищезазначеними пріоритетами у розвитку мислення та характером функціонування мови $[15,16]$. 
Прогрес властивостей уваги в юнацькому віці так само пов'язаний 3 розвитком словесно-логічного мислення. Так, серед досягнень у цьому напрямку психологи відзначають удосконалення механізму довільної уваги через здатність до цілеспрямованого зосередження свідомості на предметі діяльності, а надто до свідомих розподілу та переключення уваги. Суттєво збільшуються також інтенсивність, стійкість і обсяг уваги, що, безсумнівно, дисциплінує розумову діяльність у цілому. Зростає і роль післядовільної, або так званої вторинної мимовільної уваги, що відповідно до назви виникає на основі довільної уваги і полягає у мимовільному зосередженні на предметі цікавості або захоплення $[15,16]$.

Зростаючі досвід, знання й інтелектуальний потенціал свідчать на користь істотного підвищення рівня адекватності сприймання юнаків, який визначається мірою відповідності образа тому об’єкту, котрий сприймається. Домінування довільної форми сприймання в юнацькому віці, на думку вчених, є сприятливим фактором для подальшого розвитку таких його властивостей, як цілісність, осмисленість, вибірковість й апперцепція $[15,16]$. Остання, до речі, набуває провідного значення як властивість, яка відображає залежність сприймання від уже доволі достатнього попереднього досвіду особистості в даному віці. Психологами доведено, що саме апперцепція визначає чіткість, правильність і міцність засвоєння нових знань, й, відповідно, впливає на дієвість механізмів мислення, уваги тощо [15].

Завдяки розвитку здатності до регуляції розумової діяльності значно покращується й керування власною уявою, як процесом, що забезпечує випереджальний характер пізнання дійсності на основі набутого досвіду. Тож, у підлітковому віці механізм уяви набуває самостійності завдяки активній, внутрішній, перетворювальній діяльності [15]. В умовах суттєвого ускладнення навчального матеріалу, який доводиться опановувати на етапі старшого юнацького віку, здатність довільно спрямовувати уяву на прогнозування та випереджальне відображення реальності $\epsilon$ надзвичайно затребуваною. Так само як активізація відтворювальної (репродуктивної) уяви, що доповнює роботу наочно-образного мислення та відтворює вже відомий образ, якого проте ще не було в досвіді особистості, так і розвиток творчої (продуктивної) уяви, спрямованої на створення абсолютно нового образу, укріплюють пізнавальні й антиципаційні властивості уяви юнаків.

Відтак, юнацький вік за своїм психологічним змістом є переламним у розвитку мислення. Визнане найскладнішим видом розумової діяльності, абстрактне мислення оперує не образами, а словесно вираженими поняттями, що відображають найістотніші ознаки предметів і виникають на основі суджень та умовиводів, стаючи не лише предметом вивчення, але й інструментом пізнання [3]. Отже, 3 активізацією понятійного мислення в юнацькому віці прискорюється і свідомий розвиток аналітичних здібностей і вдосконалення наявних логічних операцій: аналізу, синтезу, порівняння, абстрагування, конкретизації, узагальнення. Саме через актуалізацію та активізацію вказаних розумових дій мислення в юнацькому віці оцінюється вченими, як більш організоване і послідовне, системне і продуктивне, з широким варіюванням когнітивних стилів залежно від глибини, гнучкості, широти, швидкості, самостійності, критичності та інших індивідуальних відмінностей $[7,11,16]$.

Психологи відзначають, що з активізацією словесно-логічного мислення виникають не лише нові інтелектуальні якості, але й відповідні потреби. Серед показників розвитку понятійного мислення юнаків вказують на зростаючу допитливість і свідому потребу в пізнанні, причому в пізнанні самостійному, керованому лише логікою міркувань, але не інструкціями та настановами. Така «пізнавальна жагучість» юнаків підкріплюється їх стрімко зростаючими аналітичними здібностями, а також спирається на їх завзятість у встановленні причинно-наслідкових зв’язків і співставленні нових знань 3 наявними [11].

Доведений експериментальним шляхом високий рівень словесно-логічного мислення юнаків [11] підсилюється, на думку вчених, такими його віковими характеристиками, як:

- конвертованість, або висока гнучкість і здатність швидко коригувати напрямок думки та легко знаходити нові стратегії мислення;

- дивергентність, або продукування декількох рішень однієї проблеми та вільне оперування гіпотезами;

- креативність, або уміння вирішувати нестандартні проблеми;

- paц̧іональність і критичність як схильність до чіткого пояснення причин i сконцентрованість на логічних зв'язках;

- неконформність, або здатність висувати ідеї, не схожі на інші, та знаходити рішення, відмінні від очевидних $[7,11,16]$. 
У поєднанні з високим рівнем поінформованості сучасної молоді в умовах вільного доступу до широкого спектру відкритих освітніх ресурсів вказані характеристики мислення гарантують значний інтелектуальний потенціал і забезпечують високу інтелектуальну активність в юнацькому віці. До того ж, досліджені вченими метакогнітивні вміння юнаків, такі як самоконтроль і саморегуляція, дозволяють піднятися на ще вищий так званий мета-рівень $\mathrm{i}$ практикувати метамислення, або мислення про своє мислення та забезпечити адекватні самооцінку та саморегуляцію власних розумових здібностей і в такий спосіб дисциплінувати власну розумову діяльність.

Будучи мисленням вторинного, більш загального порядку, метамислення становить основу для розвитку метакомпетентностей, що на сьогодні визнаються важливим особистісним ресурсом вирішення професійних завдань високого рівня невизначеності. Зважаючи на те, що ситуації невизначеності становлять один із найпоширеніших викликів у роботі моряка та $\epsilon$ джерелом виникнення професійних ризиків, такі найвищі вміння (вміння метарівня), як-от здатність учитися, адаптуватися, передбачати та нестандартно мислити, набувають надзвичайної ваги для майбутніх моряків. Незалежно від того, чим зумовлена невизначеність, чи то зовнішніми обставинами, чи поведінкою посередників, чи певними внутрішніми суб'єктивними факторами, 3 точки зору психології [10], саме вона $є$ індикатором компетентності фахівця, надаючи йому шанс виявити весь свій потенціал, усі наявні здібності.

\section{ЛIТЕРАТУРА}

1. Азимов, Э. Г., Щукин, А. Н. (2009) Новый словарь методических терминов и понятий (теория и практика обучения языкам) (с. 203), М.: Издательство ИКАР.

2. Бершедова, Л.И. (2010) Личностные новообразования критических периодов детства // Научные ведомости. Серия Гуманитарные науки, № 12 (83), Выпуск 6, 148-154.

3. Выготский, Л. С. (2004) Психология развития ребенка (с. 512), М: Изд-во Смысл, Изд-во Эксмо, (Серия «Библиотека всемирной психологии»).

4. Ляховицкий М.В. (1982) Принципы и методы обучения иностранным языкам. Н.И. Гез (Ред.), Методика обучения иностранным языкам в средней школе. Учебник. (с. 58-74). М.: Высш. школа.

5. Зимняя, И. А. (2000) Педагогическая психология. Учебник для вузов. (2-е изд., доп., испр. и перераб.). М.: Издательская корпорация «Логос»

6. Зязюн, І. А. (2013) Аксіологічні критерії вікової психології. Освіта дорослих: теорія, досвід, перспективи, № 7, 6-24. Узято з http://nbuv.gov.ua/UJRN/OD_2013_7_3

7. Калмыкова, З. И. (2011) Продуктивное мышление как основа обучаемости, М.: ЮНИТИ.

8. Кочнева, Е. М., Жарова, Д. В., Костылева, Е. А. (2016) Учебно-профессиональная деятельность студентов и ее специфика в контексте подготовки обучающихся вуза к проектированию своего профессионального будущего (Т. 5, № 4 (17), с. 362-368), АНИ: педагогика и психология.

9. Кунанбаева, С.С. (2010) Теория и практика современного иноязычного образования. - Алматы.

10. Леонтьев, Д.А. (2015) Вызов неопределенности как центральная проблема психологии личности. Психологические исследования (Т. 8, № 40). Взято из https://psystudy.ru/index.php/num/2015v8n40/1110leontiev40.html

11. Львова, Т. А. (2016, ноябрь 23) Типы мышления в юношеском возрасте. Взято из https://nsportal.ru/vuz/psikhologicheskie-nauki/library/2016/11/23/tipy-myshleniya-v-yunosheskom-vozraste-0

12. Ніколаєва, С.Ю. (2013) Система навчання іноземних мов і культур. Методика навчання іноземних мов і культур: теорія і практика: підручник для студ. класичних, педагогічних і лінгвістичних університетів (сс.110-122), К.: Ленвіт.

13. Гальскова, Н.Д. (2017) Основы методики обучения иностранным языкам: учебное пособие (сc.8286), Москва: КНОРУС.

14. Полозенко, О.В., Омельченко, Л.М., Яшник, С.В., Свистун, В.І., Стахневич, В.І., Мартинюк, І.А., Жуковська, Л.М. (2009). Основи загальної психології: Навчальний посібник (Т. 1-2). К.: НУБіП.

15. Обухова, Л. Ф. (Ред.), Бурменская, Г. В. (Ред.). (2001) Ж. Пиаже Эволюция интеллекта в подростковом и юношеском возрасте (сс. 232-243). Жан Пиаже: теория, эксперименты, дискуссии, М.: Гардарики.

16. Рогова, Г.И., Рабинович, Ф.М., Сахарова, Т.Е (1991). Методика обучения иностранным языкам в средней школе, М.: Просвещение.

17. Селігей, П.О. (2009) Структура й типологія мовної свідомості. Мовознавство, 5, 12-29.

18. Тарнопольський, О. Б., Кабанова, М. Р. (2019) Методика викладання іноземних мов та їх аспектів у вищій школі: підручник, Дніпро: Університет імені Альфреда Нобеля.

19. Щукин, А.Н. (2004) Обучение иностранным языкам: Теория и практика: Учебное пособие для преподавателей и студентов, М.: Филоматис.

20. STCW. International Convention on Standards of Training, Certification and Watchkeeping for Seafarers, 1995 (amended in 2010). (2012). London, IMO. Retrieved from http://www.seajobs.ru/sea_programms/STCW95.pdf 